\title{
A Construção do mito de Tiradentes: de mártir republicano a herói cívico na atualidade
}

\author{
The construction of the myth of Tiradentes: \\ of republican martyr to the civic hero in the present time
}

Carlos Roberto Ballarotti*

RESUMO

Este trabalho objetiva analisar, dentro da historiografia, a construção republicana do mito de Tiradentes, a partir da memória popular, para justificar e consolidar o poder vigente. Desta forma, efetuamos uma pesquisa bibliográfica sobre o assunto, verificando a profundidade da atuação do poder dominante na criação do herói, suas várias faces construídas em diferentes contextos e épocas históricas, além do papel do historiador dentro deste processo. Conferimos, também, como acontece a sobrevivência do mito de mártir e sacrificado de Tiradentes na contemporaneidade, através do livro didático em nossas instituições de ensino, nos discursos políticos e conforme os meios de comunicação.

PAlavRaS-CHAVE: História do Brasil; Tiradentes; República; Herói cívico; Imaginário popular; Brasil.

\section{ABSTRACT}

This research has the objective to analyze, inside of the historiography, the republican construction of Tiradentes's myth, from the popular memory, to justify and consolidate the affective power. In such a way, a bibliographic research was effected about the subject, verifying the depth of the performance of the dominant power in the hero's creation, its several faces constructed in different contexts and historical times, beyond the paper of this historian inside of this process. We confer, also, as the survival of the myth of martyr and sacrificed of Tiradentes in the contemporary, through the didactic book in our institutions of education, the speeches politicians and in agreement medias.

KEYWORDS: History of Brazil; Tiradentes; Republic; Civic hero; Popular memory; Brazil.

\section{Introdução}

Heróis e vilões realmente existiram? Ou se existiram, tinham toda a coragem, determinação, virtudes e foram as causas dos resultados alcançados? Ou tudo seria uma construção? O que realmente sabemos, e que não podemos nos esquecer, é que a história é escrita pelos vencedores, enquanto os perdedores são sepultados em algum lugar obscuro do passado.

Existem vários casos de manipulação histórica para a criação de uma

\footnotetext{
Mestrando em História Social orientador pelo Prof. Dr. Jozimar Paes de Almeida pela na Universidade Estadual de Londrina (UEL) / Brasil.
} 
memória dentro de determinadas sociedades, como é o caso da civilização asteca, que destruiu seu verdadeiro passado histórico, e criou um novo mito de origem $^{1}$ e até mesmo a Revolução Francesa, em que nasce o espírito de orgulho nacional francês. Não é, porém, nosso objetivo explorar a criação de tais construções.

No Brasil, desde cedo, se buscou construir manipulações consideradas dominantes, tais como: a do descobrimento destas terras, com a polêmica descoberta acidental ou intencional; bem como a imagem registrada no imaginário popular da independência, como se fosse ocorrida segundo o quadro de Pedro Américo; ou no orgulho nacional da vitória das tropas brasileiras na Guerra do Paraguai.

A escrita dominante é encontrada na história, no Brasil colônia e Brasil monárquico. Como demonstra José Murilo de Carvalho em A Formação das Almas (1990), nunca a construção histórica esteve tão presente em nossa nação como na transição da Monarquia para a República. Nesse momento, o poder político sentiu necessidade da criação de valores republicanos na consciência popular, valendo-se, para isto, de uma ideologia que ajudou a construir os símbolos, as alegorias, os rituais e mitos do novo regime.

Os republicanos brasileiros tiveram uma árdua tarefa para a construção destes símbolos e contaram com a ajuda dos positivistas, presentes nas fileiras do Partido Republicano. Dentre os vários símbolos criados pela República, alguns tiveram a aceitação pelo público, como é o caso do maior símbolo nacional, ou como se refere o autor Paulo Miceli (1994), o herói nacional, Tiradentes.

Tiradentes não foi criado pela República, mas sua imagem foi apropriada pelos vencedores, uma vez que o novo regime necessitava de uma figura forte que apagasse o então herói D. Pedro I, a imagem forte da monarquia: "A luta em torno do mito de origem da República mostrou a dificuldade de construir um herói para o novo regime" (CARVALHO, 1990: 55). O herói republicano deveria ser um instrumento eficaz para atingir a cabeça e o coração do povo. Assim, vários foram os candidatos ao preenchimento da vaga no panteão da República.

1 Este fato -um novo mito de origem do povo asteca-, é comentado por Enrique Florescano, estudioso mexicano, em discurso proferido na Academia Mexicana de História em julho de 1989, no qual discorre sobre a construção de um novo passado para o povo asteca, inspirado na civilização que existia naquele local, antes da chegada dos fundadores de Tenochtitlan. 
O vencedor do concurso, metaforicamente, foi Tiradentes e não poderia ser outro. A República tratou de conferir um rosto ao herói, pois que o mesmo não deixou um retrato. Assim, criou bustos, quadros, data comemorativa e histórias: Tiradentes pode aparecer como Jesus Cristo (de barba e cabelos compridos) ou elegante e bonito em sua roupa de alferes. A imagem não importava, mas, sim, o ideal que Tiradentes representava e que a República queria alcançar.

Hoje, Tiradentes vive no imaginário popular como uma entidade sacrificada a favor do futuro da nação. "Tiradentes ajudou o povo, sofreu por ele, e acabou morrendo por ele" (MICELI, 1994: 25). Esta é uma das imagens que os estudantes passaram a Paulo Miceli, em sua pesquisa sobre o herói nacional.

José Murilo de Carvalho mostra que a República se apoderou da memória popular, referente a Tiradentes, e transformou sua figura em herói republicano.

$\mathrm{O}$ que acontece nos dias atuais, e que ainda é transmitido aos nossos alunos de ensino fundamental, é o ideal de que Joaquim José da Silva Xavier, vulgo Tiradentes, é um herói nacional. Não é o objetivo deste trabalho o de destruir a aura heróica do personagem histórico, mas, sim, descobrir o porquê da construção de sua imagem de herói republicano.

Este estudo busca verificar os motivos, pelos quais, o personagem continua forte como herói, dentro da preferência nacional, até os dias atuais.

Até que ponto um poder pode influenciar a leitura histórica? Poderia, nos dias atuais, existir algum exemplo da apropriação de um personagem histórico para justificar alguma atitude da classe dominante ou de alguma figura no poder?

No primeiro tópico comentamos sobre a utilização da imagem de Tiradentes pelo poder republicano através do imaginário social. Trabalhamos, além da obra de José Murilo de Carvalho (1990), com outros autores que discutem a imagem de Tiradentes, como Paulo Miceli (1994) e Silva Jardim (1890).

No Segundo momento deste trabalho, o mito de Tiradentes é utilizado como um pano de fundo, para procurar entender como é construída a história. Seria o papel do historiador a de um romancista, como comenta Paul Veyne em sua obra Como se escreve a história? (1998). Seria, ainda, nos dias atuais, o positivismo servindo à história ou a história é uma invenção? Procuramos 
chegar a uma conclusão revisitando alguns autores que debatem sobre este assunto e utilizamos o exemplo vencedor da criação do mito pelo poder republicano em nosso país.

No terceiro tópico verificamos como é transmitida a imagem de Tiradentes na contemporaneidade, através dos livros didáticos, que são repassados aos nossos alunos e pelos meios de comunicação, verificada através de uma pesquisa em determinados livros didáticos encontrados em bibliotecas escolares e também livros utilizados nas salas de aula.

Em sua obra $A$ história repensada com ousadia (2001), o autor Keith Jenkins afirma que o historiador não inventa histórias sobre o mundo ou sobre o passado. Ele apenas constrói um discurso pelo qual o mundo faz sua leitura, sendo que o passado sempre nos chega como uma narrativa e jamais poderemos verificar se estas narrativas correspondem realmente à realidade.

Observando este ponto de vista, a história, segundo determinados princípios, seria uma especulação, hoje digna de crédito, mas, amanhã, em virtude de novas linhas de pensamentos ou provas concretas pode ser alterada completamente. Há que se ter em mente que a leitura histórica é um processo contínuo.

\section{Tiradentes e a República}

A Inconfidência Mineira é um fato nacional que divide os historiadores sobre sua importância dentro do movimento para libertação do Brasil da dominação portuguesa. Com a execução de Tiradentes e punições menos severas aos demais envolvidos, a Coroa Portuguesa utilizou-se desse fato como exemplo, dirigido aos colonos com idéias emancipatórias.

Esse mesmo acontecimento foi utilizado na transição da Monarquia para a República para promover a instalação e consolidação do poder republicano no Brasil. No período do regime cívico-militar, inaugurado em 1964, Tiradentes voltou à tona em várias leis que regulamentavam sua figura heróica.

Frente à dificuldade em se encontrar um herói para a República, ${ }^{2}$ foi-se encontrá-lo longe da proclamação, há exatos cem anos atrás, na figura de

2 Primeiramente, se cogitou a figura do Marechal Deodoro da Fonseca como símbolo da República, entretanto, sua imagem se assemelhava ao monarca D. Pedro II e seu republicanismo era considerado incerto, e outros candidatos como Benjamin Constant e Floriano Peixoto não possuíam o apoio de todos os republicanos. 
Tiradentes. Para o historiador Sérgio Vaz Alkmin, há um certo consenso entre os brasileiros em torno de Tiradentes como herói da pátria. E é

fácil entendermos o porquê. Tiradentes foi morto e esquartejado porque queria a República. E isso quando o Brasil ainda era submetido ao império português [...]. Com o advento da República, buscava-se um herói republicano, e ali o tinham (ALKMIM, 2006).

Essa escolha, segundo o historiador, não se deveu apenas por ter sido ele um defensor do regime republicano; deveu-se à imagem de sua figura modelada na memória popular com a qual o povo brasileiro se identificava-a figura de um mártir sacrificado, assim como Cristo:

Tudo isso calava profundamente no sentimento popular, marcado pela religiosidade cristã. Na figura de Tiradentes todos podiam identificarse, ele operava a unidade mística dos cidadãos, o sentimento de participação, de união em torno de um ideal, fosse ele a liberdade, a independência ou a república. Era o totem cívico. Não antagonizava ninguém, não dividia as pessoas e as classes sociais, não dividia o país, não separava o presente do futuro. Pelo contrário, ligava a república à independência e a projetava para o ideal de crescente liberdade futura (CARVALHO, 1990:68).

José Murilo de Carvalho também destaca o fator geográfico, na escolha de Tiradentes -o herói pertencia ao centro político do país: Minas, Rio e São Paulo.

\section{O imaginário social}

Bronislaw Baczo, em estudo da construção do imaginário, salienta seus significados e funções, propondo questões relativas às ligações entre imaginário, política, transformação social e permanências. Para o autor,

só com a instalação do poder estatal, nomeadamente o poder centralizado, e com relativa autonomia a que acede o domínio político, é que as técnicas de manejo dos imaginários sociais se desritualizam, ganhando em autonomia e diferenciação (BAZCO, 1984: 300).

Com essa afirmativa, o autor coloca o domínio do símbolo ligado ao poder e o poder diretamente ligado ao Estado. Essa ligação formal do imaginário a serviço do poder e do Estado é incorporada por José Murilo de Carvalho, que afirma:

\footnotetext{
A elaboração de um imaginário é parte integrante da legitimação de qualquer regime político. É por meio do imaginário que se pode atingir não só a cabeça mas, de modo especial, o coração, isto é, as aspirações, os medos e as esperanças de um povo. É nele que as sociedades definem suas identidades e objetivos, definem seus inimigos, organizam seu passado, presente e futuro (CARVALHO, 1990:10).
}

O mesmo autor, ao comentar a batalha ideológica e política para 
implantação de valores republicanos no povo brasileiro, complementa que o imaginário social é constituído por ideologias e utopias, mas também através de símbolos, alegorias rituais e mitos. Os mitos podem se tornar elementos poderosos de projeção de interesses e aspirações (CARVALHO, 1990:10-11).

Essa manipulação do real ocorre quando, em momentos de mudança política e social, a necessidade de redefinição de identidades coletivas se impõe.

Segundo Marilena Chaú, a ideologia não é só a representação do real para servir ao exercício de dominação em uma sociedade fundada na luta de classes. Não é, também, só a inversão imaginária do processo histórico, na qual, as idéias ocupariam os espaços dos sujeitos históricos reais. A ideologia,

\begin{abstract}
forma específica do imaginário social moderno, é a maneira necessária pela qual os agentes sociais representam para si mesmos o aparecer social, econômico e político, de tal forma que esta aparência (que não devemos simplesmente tomar como sinônimo de ilusão ou falsidade), por ser o modo imediato e abstrato de manifestação do processo histórico, é o ocultamento ou a dissimulação do real (CHAUÍ, 1997: 03).
\end{abstract}

Se existe a implantação de tal interesse na história, também existe a luta pela preservação da memória, conforme destaca Jacques Le Goff:

\begin{abstract}
a memória coletiva foi posta em jogo de forma importante na luta das forças sociais pelo poder. Tornarem-se senhores da memória e do esquecimento é uma das grandes preocupações das classes, dos grupos, dos indivíduos que dominaram e dominam as sociedades históricas. Os esquecimentos e os silêncios da história são reveladores desses mecanismos de manipulação da memória coletiva (LE GOFF, 1984:103).
\end{abstract}

Para esse autor, o estudo da memória pode ajudar muito o historiador a descobrir os limites do poder e a ação das classes dominadas, no rumo da história.

\title{
Como se escreve a História
}

Além da imprensa, 3 a república obteve auxílio de vários historiadores que ajudaram a conjugar a figura do mártir com o ideário republicano. Mas, qual foi o papel do historiador dentro desta construção histórica?

\footnotetext{
3 Se o poder republicano tornou Tiradentes um herói nacional, grande parte deste resultado, se deve aos jornais que, a partir do século XX, produziram um rico material de registros sobre a Inconfidência Mineira e seu herói, ajudando no processo de difusão e de consolidação das representações republicanas. Entre as décadas de 1930-1960, os jornais publicaram textos de autoria variada: historiadores com tendências mais tradicionais em geral ligados a institutos históricos, juristas, diplomatas, políticos, professores, cronistas, romancistas, poetas, jornalistas, intelectuais católicos e clérigos.
} 


\title{
Os positivistas
}

Nesse momento, quem mantinha as rédeas sobre a história, eram os positivistas ortodoxos, que se envolveram intensamente na construção do herói nacional -Tiradentes- e formaram, "sem dúvida, o grupo mais ativo, mais beligerante, no que diz respeito à tentativa de tornar a República um regime não só aceito como também amado pela população." (CARVALHO, 1990: 129).

Os positivistas tinham como armas, a escrita e os símbolos cívicos e o historiador, naquela época, seria

\begin{abstract}
basicamente um autodidata, precisava unicamente do reconhecimento de seus pares - o universo dos intelectuais - para ser aceito, de fato e de direito, como historiador. [...] esses historiadores, ou os mais eruditos entre eles, dispunham também de manuais e tratados famosos e alentados acerca do que então se denominava metodologia cientifica da História (FALCON, 1995: 2).
\end{abstract}

Para os positivistas era necessário implantar na consciência popular um espírito de civismo e nacionalismo, razão pela qual colocaram os fatos históricos a seu serviço. Fizeram algumas alterações e embutiram algumas alegorias para que a história ficasse mais interessante.

Nesse sentido, para Langlois e Seignobos, o historiador é um educador cívico e o valor da história "é sobretudo pedagógico [...]. Na educação cívica, os fatos históricos e os grandes homens são cuidadosamente reconstituídos e embalsamados para a instrução da juventude. Faz-se uma história comemorativa, que legitima os rituais cívicos.” (REIS, 1995: 53).

Para estes historiadores os grandes eventos, produzidos por grandes sujeitos, que atuam na história, favorecem o desenvolvimento da nação e a realização da democracia. Seria, então, imprescindível que esses historiadores trabalhassem em conjunto com o poder, colaborando diretamente na chamada Historiografia oficial: "Por isso escreve-se uma história feita pelos grandes homens: exaltando os heróis antigos, esforçam-se para identificá-los com as autoridades atuais" (CHIAVENATO, 1994: 9).

A exaltação da figura de Tiradentes, identificada à autoridade vigente, foi utilizada à exaustão, como no fragmento do discurso de Getúlio Vargas, em Minas Gerais, no governo de Juscelino Kubitschek, de quem recebia apoio político, em um período de seus mais duros embates com a oposição. Vargas assegura ser Minas o lugar ideal para a busca do consenso, da harmonia e destaca as tradições mineiras como capazes de serenar os ânimos naquele 
tumultuado e delicado momento político. Afirma que não iria permitir que "interesses mesquinhos" se impusessem aos interesses da nação e que seria tarefa de seu governo, garantir a ordem, a liberdade [...]: "O exemplo de Tiradentes e a lição de Minas nos darão força para construir no futuro um Brasil que corresponda aos sonhos do passado, em que alcancem as esperanças do presente". (VARGAS apud FONSECA, 2002: 22-23).

Vargas voltava ao passado e buscava Tiradentes, para garantir sua sustentação e legitimação política.

Na política é freqüente a busca e a comparação com algum personagem forte da história, para consolidação de imagem ou aceitação política. O próprio Vargas, que empregou este artifício, também foi utilizado por políticos posteriores a ele.

Este tipo de endeusamento de mitos políticos se faz presente em toda a história mundial e está nas mãos do historiador decidir o que sobrevive ao passado, embora a classe dominante também faça a sua escolha. O que sobrevive

não é o conjunto daquilo que existiu no passado, mas uma escolha efetuada, quer pelas forças que operam no desenvolvimento temporal do mundo e da humanidade, quer pelos que se dedicam à ciência do passado e do tempo que passa, os historiadores (LE GOFF, 1994: 95).

É sobre como funciona este processo, ao qual, leva a sobrevivência de certos fatos passados até o presente, como assinalado por Le Goff, que tentamos entender neste trabalho.

\title{
O papel do historiador
}

Para Keith Jenkins, o historiador trabalha com ferramentas analíticas e metodológicas para construir o passado num discurso palatável aos leitores. É

\begin{abstract}
nesse sentido que lemos o mundo como um texto, e tais leituras são, pela lógica, infinitas. Não quero dizer com isso que nós simplesmente inventamos histórias sobre o mundo ou sobre o passado (ou seja, que travamos conhecimento do mundo ou do passado e então inventamos narrativas sobre ele), mas sim que a afirmação é muito mais forte: que o mundo ou o passado sempre nos chegam como narrativas e que não podemos sair dessas narrativas para verificar se correspondem ao mundo ou ao passado reais, pois elas constituem a realidade. (JENKINS, 2001: 28).
\end{abstract}

Podemos concordar com as palavras do historiador, contudo, existem inúmeras "verdades" aceitas, segundo as linhas de pensamento e o momento, no 
qual, suas escolhas foram feitas. Como assinala Le Goff, o perigo está na transformação de uma linha de interpretação, como a única verdade aceita.

De uma maneira bem mais apocalíptica, Walter Benjamin, discute sobre o passado e o presente no ofício do historiador e destaca o perigo ao qual ele incorre em seu trabalho:

Articular historicamente o passado não significa conhecê-lo "como ele de fato foi”. Significa apropriar-se de uma reminiscência, tal como ela relampeja no momento de um perigo. Cabe ao materialismo histórico fixar uma imagem do passado, como ela se apresenta, no momento do perigo, ao sujeito histórico, sem que ele tenha consciência disso. $\mathrm{O}$ perigo ameaça tanto a existência da tradição como os que a recebem. Para ambos, o perigo é o mesmo: entregar-se às classes dominantes, como seu instrumento. Em cada época, é preciso arrancar a tradição ao conformismo, que quer apoderar-se dela. Pois o Messias não vem apenas como salvador; ele vem também como o vencedor do Anticristo (BENJAMIN, 1987: 224).

Benjamin destaca que o perigo, segundo o momento histórico vivido, está em transformar os fatos históricos em verdades supremas, entregando a justificação dos mesmos à utilização das classes dominantes, como mecanismo de manipulação. No caso específico da construção do mito em torno de Tiradentes, o perigo se concentra na continuidade da dominação, segundo Chiavenato:

\begin{abstract}
A historiografia oficial, zelosa em criar heróis para o panteão da pátria, falsifica figuras como o Tiradentes, exaltando posturas alienadas, idealistas. É muito importante quebrar a linha dessa mistificação histórica que visa, entre outras coisas, manter a dominação ideológica, impondo a visão da nossa história filtrada pelos poderosos. Em suma, impõe-nos a sua história, e assim nos desarmam para a resistência cultural, política e etc. (CHIAVENATO, 1994: 08).
\end{abstract}

Para não se correr este risco, o autor assinala a importância de nos preocuparmos com as outras histórias, dentro do mesmo evento. Pode-se dizer que "no caso da Inconfidência a verdade tem várias faces. Mas como se crê que a verdade é uma só, deve-se, estudar cada face dos acontecimentos para tentar aproximar-se mais daquilo que se poderia chamar de realidade objetiva" (CHIAVENATO, 1994: 10).

Além destas várias faces, há o conhecimento que foi esquecido, ou considerado não relevante. Em Genealogia do poder, Foucault questiona os conteúdos históricos que foram sepultados ou mascarados em sistematizações formais, ao se referir à história dos manicômios e das prisões. A história decorrente desses conteúdos sepultados, o autor denomina de "saber dominado". Nesse sentido, ele está constituído por blocos "de saber que tinham 
sido desqualificados como não competentes; seriam saberes ingênuos colocados abaixo do nível requerido pelo conhecimento comprovado" (1982: 170).

O autor destaca que o reaparecimento desses saberes - de marginais, enfermeiros, médicos marginais (em relação ao saber médico), esquizofrênicos, delinqüentes, entre outros -, veio à tona por meio de instrumentos de erudição e permitiram que se realizasse a crítica e, ao mesmo tempo, se redescobrisse a exata dimensão das lutas "e memórias dos combatentes". Isso só foi possível quando se conseguiu eliminar a "tirania dos discursos englobantes com suas hierarquias e com os privilégios da vanguarda teórica”. Isso se deu a partir da associação "entre o saber sem vida da erudição e um saber particular e desqualificado que deu à crítica [...] sua força essencial” (FOUCAULT, 1982: 170-171).

Para o historiador Adam Schaff, o conhecimento é o resultado do acúmulo de verdades parciais que a humanidade estabelece nas diversas fases do seu desenvolvimento histórico: “alargando, limitando, superando estas verdades parciais, o conhecimento baseia-se sempre nelas e toma-as como ponto de partida para um novo desenvolvimento" (1978: 97).

Nesta linha de pensamento, pode-se, concordar com Schaff e seguir seu raciocínio para demonstrar algumas vertentes sobre a vida de Tiradentes. Verifica-se, então, referente sua aparência, a existência de duas figuras. Segundo Joaquim Norberto4, Tiradentes era "feio, ignorante, falastrão, pobre, inconveniente, que foi admitido nos meios inconfidentes e ainda, por irresponsabilidade, colocou tudo a perder" (LETTIERE, 2001: 23).

Segundo seus críticos, esta imagem creditada a Tiradentes provém do fato de Norberto ser monarquista, amigo do Imperador D. Pedro II e almejar algum título nobiliárquico.

Entretanto, a imagem de Tiradentes existente em outra obra, a do historiador Silva Jardim, em 1890, para quem, era a de

um homem alto, magro, porém musculoso, de largas espáduas, cabelos a meio encanecidos a caírem-lhe anelados, fisionomia impressionadora, notável o olhar, cheio de estranha vida [...]. Era eloqüente em suas palavras e gestos, e muitas vezes ungia-lhe $o$ entusiasmo. O trato insinuante e lhano, de modo a cercar-se de relações, expansivo e rude a ponto de afugentar os tímidos e penetrar

\footnotetext{
4 Joaquim Norberto de Souza Silva foi o responsável pelo primeiro trabalho sustentável de um historiador brasileiro sobre a Inconfidência Mineira com a obra História da Conjuração Mineira, publicada em 1873.
} 
os másculos. Não era belo (JARDIM, 1890: 35).

Silva Jardim, republicano radical, teria construído uma imagem cívica para Tiradentes, embora não se saiba, ao certo, de qual fonte ele tirou estas informações.

Nestes discursos, verifica-se a utilização de adjetivos que enaltecem ou desprestigiam o herói: a primeira, por questões políticas, constrói uma imagem que desqualifica Tiradentes; a segunda, também por motivos políticos, o enaltece. Ou seja, os interesses pessoais interferiram na objetividade que deveria existir na construção do conhecimento sobre o passado.

Importante ressaltar que a imagem construída por Norberto segue os passos de Varnhagen, outro historiador monarquista, para quem, Tiradentes "era bastante alto e muito espadaúdo, de figura antipática, "feio e espantado" (VARNHAGEN, 1980: 65).

Considerado "pai" da história do Brasil, Varnhagen, por ser de família monarquista, descreveu Tiradentes como "antipático", portanto incapaz de ter recebido a tarefa de ser o propagandista da conjuração.

$\mathrm{O}$ poder republicano utilizou-se de vários historiadores, como o autor Augusto de Lima Júnior, que recebeu financiamento do governo, para escrever a obra Pequena História da Inconfidência, em 1955, exaltando o heroísmo de Tiradentes e dos inconfidentes.

Por sua vez, pessoas que viveram o momento histórico da Inconfidência Mineira, também, têm o que dizer sobre o Tiradentes de seu tempo. O Visconde de Barbacena, ao saber sobre os planos de uma revolução do inconfidente, disse: "Só se for uma revolução de meretrizes. Dêem nesse maroto com um chicote. Ele é um bêbado" (BARBACENA, apud MURY, 1973: 197).

Esta era a imagem que o governador das Minas Gerais tinha de Tiradentes. Porém, nos depoimentos dos "Autos da Devassa", verificamos outro tipo de declaração vinda de superiores. Era

\begin{abstract}
audacioso, conseguiu melhor contato com seu comandante. E, um dia, firme e corajosamente, abordou o tenente-coronel Francisco de Paula Freire de Andrade sobre a Conjuração Mineira. A atitude causou forte estranheza ao chefe das tropas, pois não supunha aquele subordinado capaz de tamanha afoiteza, conforme declarou, em seus depoimentos à Devassa. (MURY, 1993: 65)
\end{abstract}

Contudo, como uma pessoa considerada desequilibrada poderia conseguir o apoio de seu comandante, e assim, da elite militar para com a conjuração? 
Existe, segundo Lydia Mury, outra pendência historiográfica em relação à Inconfidência Mineira, na qual, diz respeito à profundidade das propostas dos conjurados. Entretanto, o historiador da Inconfidência conta apenas com os "Autos da Devassa" para conseguir reviver a história, pois os envolvidos destruíram suas anotações ao serem presos.

Como tais Autos, se constituem, por um lado, nos únicos documentos que contêm os depoimentos do julgamento de Tiradentes e dos demais participantes da conjuração e, por outro, foram produzidos pelo poder, eles apresentam, já na sua origem, os limites de sua produção - fonte oficial com o poder de punir. Segundo Cezar Honorato, há neles "a dicotomia entre o discurso falado e o impresso. Ao discurso falado se deu ênfase, pelas limitações da fonte, no que se refere aos interrogatórios de Tiradentes" (1990: 281).

Os limites, proclamados por Honorato, estão no fato de trazerem os depoimentos de forma distorcida, pois, o que se buscava era culpar e denegrir os envolvidos. Esses limites indicam que, para se trabalhar com os "Autos da Devassa", é preciso, antes de tudo, ter profundo conhecimento da documentação sobre a Inconfidência, para se poder encontrar as distorções presentes nos mesmos.

Este é outro aspecto que ronda o historiador. Baseado nos documentos ou outras fontes históricas, como a iconografia, o pesquisador transforma aquele objeto em uma narrativa: "a história depende dos olhos e da voz de outrem: vemos por intermédio de um interprete que se interpõe entre os acontecimentos passados e a leitura que deles fazemos" (JENKINS, 2001: 32).

Para Paul Veyne, o historiador seria como um romancista, porque a

história é uma narrativa de eventos: todo o resto resulta disso. Já que
é, à primeira vista, uma narrativa, ela não faz reviver esses eventos,
assim como o faz o romance [...]. Como o romance, a história
seleciona, simplifica, organiza, faz com que um século caiba numa
página, e essa síntese da narrativa é tão espontânea quanto à da nossa
memória, quando evocamos os dez últimos anos que vivemos
(VEYNE, 1998: 11).

Nestes termos, a história é como um "romance verdadeiro", na perspectiva de que o pesquisador coloca-se diante das fontes, na busca do indício das relações que encadeiam os eventos selecionados para, assim, fornecer uma interpretação que lhe confere algum sentido.

Ao pensar a história em tais termos, o autor não está chamando a atenção para a forma narrativa, mas reafirmando a responsabilidade do historiador, por 
ser ele que tecerá a intriga, ao escolher o evento que deverá fazer parte do enredo, influenciando toda uma geração de historiadores e estudiosos da história.

Assim, cada geração,

em seu presente específico, une passado e presente de maneira original, elaborando uma visão particular do processo histórico. $\mathrm{O}$ presente exige a reinterpretação do passado para se representar, se localizar e projetar o seu futuro. Cada presente seleciona um passado que deseja e lhe interessa conhecer. A história é necessariamente escrita e reescrita a partir as posições do presente, lugar da problemática da pesquisa e do sujeito que a realiza (REIS, 2000: 09).

Neste aspecto, explica-se Tiradentes sob várias faces: o mártir símbolo republicano, o sacrificado como Jesus Cristo, o "bode expiatório", o líder da Conjuração Mineira, o louco e o "falastrão", o revolucionário inspirado nos ideários americano e francês, o antipático e ignorante, o expansivo e letrado e quantas mais imagens aparecerem sobre o herói.

Pode-se perguntar, qual dessas imagens seria a verdadeira? Mas isto seria importante? Marc Bloch, um dos fundadores da escola Cultural, em poucas palavras, responde a esta indagação: “A questão [...] não é mais saber se Jesus foi crucificado, depois ressuscitado. O que se trata de compreender é como é possível que tantos homens ao nosso redor creiam na crucificação e na ressurreição" (BLOCH, 2001: 58).

Não poderia existir melhor exemplo, pois, citando Cristo, Bloch insere a mesma situação para Tiradentes. Não importa se ele era o líder ou o "bode expiatório" da Inconfidência, pois, interessa verificar como é possível, que tantos homens acreditem que ele é um herói. O mesmo Maxwell que o chamou de "bode expiatório", acredita que Tiradentes foi um herói, pois enfrentou com dignidade a morte; seu comportamento, ao ser interrogado, foi exemplar; ninguém foi mais entusiasta por uma Minas independente e republicana: "Reclamou para si o maior risco e não há duvidas alguma de que estava disposto a assumi-lo [...]”. (MAXWELL, 1978: 106).

Entretanto, existe um artigo, com base nos estudos do historiador carioca Marcos Antônio Correa, publicado na Folha de São Paulo, em 21 de abril de 1998, que tenta mostrar um outro lado da história do herói.

Tiradentes não morreu enforcado em 21 de abril de 1792. Ele começou a suspeitar disso quando viu uma lista de presença da Assembléia Nacional Francesa de 1793, onde constava a assinatura de um tal Joaquim José da Silva Xavier, cujo estudo grafotécnico permitiu concluir que se tratava da assinatura de Tiradentes. Segundo Correa, 
um ladrão condenado morreu no lugar de Tiradentes, em troca de ajuda financeira à sua família, oferecida pela maçonaria. Testemunhas da morte de Tiradentes se diziam surpresas, porque o executado aparentava ter menos de 45 anos. Sustenta Correa, que Tiradentes teria sido salvo pelo poeta Cruz e Silva [maçom, amigo dos inconfidentes e um dos juízes da Devassa] e embarcado incógnito para Lisboa em 1792 (PINCA, 2006).

Esta vertente que destrói toda a história de Tiradentes até agora conhecida, também não é inédita. Existem, mesmo na região de Minas, algumas lendas a este respeito, conforme constatado por turistas que visitaram as cidades históricas da região. Um dos motivos dessa afirmativa diz respeito ao desaparecimento da cabeça do herói no primeiro dia de sua exposição na cidade de Vila Rica, a qual nunca mais foi encontrada. Se a cabeça não fosse de Tiradentes, acabariam por descobrir.

Especulações à parte, o que importa na história da Inconfidência Mineira é que a imagem de Tiradentes, enquanto herói resiste ao tempo. Mas, como a História do Brasil contínua sendo escrita, qual a história que será contada, no futuro, sobre o que está ocorrendo no presente?

Conforme Emília Viotti da Costa, na análise dos acontecimentos históricos,

é preciso ir além dos fenômenos aparentes, que são observados e registrados pelos contemporâneos. As grandes transformações que subvertem a estrutura econômica e a ordem social são às vezes silenciosas e passam despercebidas aos olhos dos contemporâneos, ou são vistas de maneira parcial e deformada. $O$ que parece relevante para os que vivem o momento histórico é, em geral, o que pode ser facilmente observado: as ações individuais, os conchavos denunciados, os episódios mais flagrantes, as intrigas mais conhecidas (COSTA, 1999: 452).

O historiador José Carlos Reis concorda com os argumentos de Costa, ao afirmar que, a reescrita contínua da história é uma necessidade, pois os acontecimentos não são transparentes e não se deixam interpretar imediatamente, enquanto é vivido (REIS, 1999:07).

Para esses historiadores, existe uma dificuldade em analisar nosso tempo presente, pois se, por um lado, estamos nele mergulhados, por outro, nossa atenção está voltada para os comportamentos individuais objeto de denúncias, tão comuns ao nosso presente. Neste aspecto em especial, temos dificuldade de buscar os motivos que levaram os homens, agora denunciados, a agir como agiram.

O historiador, tomando estes cuidados, poderá permitir um conhecimento maior da nossa história, explicando inclusive o presente. Assim, entenderá o 
comportamento das classes dominantes, que ainda hoje atuam na história.

\title{
A imagem Contemporânea de Tiradentes
}

Num popular site de relacionamento, encontram-se várias comunidades que tratam de determinado assunto. Efetuando uma busca a respeito do herói Tiradentes, é possível verificar várias comunidades dedicadas à cidade de Tiradentes e para colégios com o mesmo nome. Depois de muita pesquisa, encontramos uma única para o mártir republicano, com o título: “Tiradentes Herói brasileiro”, na qual, consta na descrição da mesma:

\begin{abstract}
Joaquim José da Silva Xavier, Tiradentes, o homem que doou a sua vida pela liberdade, que foi capaz de elaborar o programa revolucionário mais avançado da época, que incluía desde a independência do país e a proclamação da república, até a abolição dos escravos, passando pela industrialização, pelo incentivo à ocupação do território, pela mudança da capital e pela criação do ensino público e gratuito, além de universidades por todo o país (PEDRAZOLI, 2006).
\end{abstract}

A descrição acima indica que realmente o poder republicano construiu um mito fortemente solidificado, ainda nos dias atuais, portanto, contínua sendo utilizado em diversas circunstâncias, como já assinalamos.

\section{Tiradentes e o ensino}

No "Seminário 500 anos de História do Brasil", do qual participaram professores de diversos estados, Paulo Miceli observou a necessidade de atualização do ensino nas salas de aula. E, ao estabelecer paralelos entre aspectos da colonização e a atualidade, esclareceu que mitos e heróis precisam ser revistos de "forma crítica para que se possa situar o aluno num amplo contexto sócio-político, analisando tais heranças, com vistas à construção de uma nova mentalidade de brasilidade" (MICELI, 2000: 02).

$\mathrm{O}$ autor destacou, ainda, que Tiradentes deve continuar sendo lembrado pelo que significou dentro dos conceitos de independência, resistência e democratização do país.

Em sua obra "O mito do herói nacional", afirma ser Tiradentes o herói nacional preferido dos estudantes. Esta afirmativa decorre de uma pesquisa realizada com cerca de 267 estudantes, da sexta série do primeiro grau à terceira do segundo grau, que responderam várias questões relacionadas à palavra herói. 
Importa destacar as questões 1 e 7: "Quem é seu herói preferido? Por que ele é um herói?”

$\mathrm{Na}$ primeira questão Tiradentes obteve sozinho, pouco menos de um quarto do total de votos: "Trata-se, sem dúvida, de um herói preferido nacionalmente e, pode-se dizer, em todas as idades.” (MICELI, 1994: 25). A questão seguinte demonstra a imagem fixada pelo aluno: "É meu herói preferido não por sua aparência, porque de bonito não tinha nada; mas por sua cabeça, por seu pensar. A beleza não importa; o importante é o amor ao próximo”. (MICELI, 1994: 25)

Não faltaram referências à imagem de Cristo:

Tiradentes gostava de ajudar os outros e na sua morte existe uma pequena semelhança com a morte de Jesus Cristo, pois ambos lutavam por uma boa causa para ajudar a população não dominante, $\mathrm{e}$ eles foram traídos por pessoas próximas, sendo denunciados em troca de muito dinheiro (MICELI, 1994: 25).

Fisicamente o herói é citado de várias maneiras, contudo sempre "barbudo" ou "bigodudo". O que mais lembram é de sua valentia: “Tiradentes era bondoso, com várias qualidades boas e era um ótimo dentista; teve garra e um objetivo na vida: a independência do Brasil, pela qual foi injustamente morto". (MICELI, 1994: 25).

Estes exemplos refletem o conhecimento que estes alunos e jovens tiveram em suas escolas e o maior responsável por isto, como destaca Marc Ferro, é o livro didático: “a imagem que temos de outros povos, e até de nós mesmos, está associada a história tal como se nos contou quando éramos crianças. Ela deixa sua marca em nós para toda a existência.” (FERRO, 1989: 25).

Marc Ferro chama a atenção, justamente, sobre a imagem histórica transmitida pela história institucional, conhecida por nós como "história oficial”.

Como este trabalho não tem como objetivo, uma pesquisa aprofundada sobre o livro didático de História, mas recolher exemplos que confirmem a contemporaneidade de Tiradentes, foram selecionados alguns recortes de textos e efetuados comentários sobre a linha seguida por cada autor, justamente para explicar as causas do enraizamento das idéias sobre o herói, seja no criador da comunidade no site de relacionamentos ou nos alunos que participaram da pesquisa de Miceli.

Este recorte é de um livro didático publicado no ano de 1994, e a autora 
Carlos Roberto Ballarotti

A Construção do mito de Tiradentes: de mártir republicano a herói cívico na atualidade

elabora assim sua idéia sobre a história:

A história estuda o passado dos povos, trata dos acontecimentos que, por serem importantes, tiveram influência no futuro. A morte na forca de Tiradentes, por exemplo, é um grande acontecimento de nossa história. O sacrifício do patriota de Minas fortaleceu, no povo brasileiro, a vontade de se libertar do domínio de Portugal. Até hoje, a data de sua morte continua sendo comemorada com muitas solenidades: é o dia de Tiradentes (21 de abril), feriado nacional (RODRIGUES, 1994: 02).

O seguinte texto foi direcionado para alunos da quinta série e trabalha com a imagem de Tiradentes como o líder patriótico dos republicanos:

\begin{abstract}
A historiografia enfatiza sua importância, porque é um belo exemplo de luta pela liberdade nacional. A partir da proclamação da República, centraliza no Tiradentes todo o vigor e a chama libertária dos brasileiros, para criar um herói que simbolizasse a dignidade republicana (CHIAVENATO, 1994: 10).
\end{abstract}

Além de ser um exemplo perfeito de patriotismo republicano, Tiradentes ainda aparece como um herói positivista, na melhor tradição comtiana:

Os inconfidentes, liderados por Joaquim José da Silva Xavier, o Tiradentes, pretendiam proclamar a República, criar uma universidade e fundar fábricas. Mas foram traídos e presos. Tiradentes dói condenado à morte, tendo sido enforcado e esquartejado no dia 21 de abril de 1792 (PILETTI, 1989:43).

O recorte abaixo de Maxwell -“A devassa da devassa” - evidencia sua influência na elaboração de livros didáticos:

Joaquim José da Silva Xavier não foi o líder da conjura mineira, movimento sem líderes, segundo a declaração dos envolvidos, durante a devassa [...]. Apesar disso, Tiradentes pode ser considerado herói por vários motivos. Em primeiro lugar, por sua personalidade expansiva, tendo desempenhado papel de agitador político do movimento, o que o deixou em posição de vulnerável destaque. Em segundo lugar, porque foi o bode expiatório da conjura mineira, recaindo sobre ele a maior culpa na devassa (MAXWELL, 1978: 222).

Entanto, o texto seguinte reproduz a obra de Maxwell, publicada originalmente em 1978. Assim, para esta idéia chegar ao livro didático levou cerca de vinte anos:

Joaquim José da Silva Xavier, o Tiradentes, depois de três interrogatórios, resolveu confessar, mas inocentou os outros prisioneiros. Assumiu sozinho a responsabilidade do movimento e apresentou-se como seu chefe, embora fosse apenas um propagandista da conspiração. Desse modo Tiradentes foi aquele que costumamos chamar de bode expiatório ou seja, o que leva a culpa e o castigo pelos outros, para servir de exemplo (CARMOS e COUTO, 1998: 130-131).

O que foi alterado no ensino básico sobre história, desde a implantação da república até os dias atuais?

Após a proclamação da República, havia a esperança que a educação fosse 
a solução para os problemas sociais e que deveria valorizar a cultura regional:

Dentro da melhor tradição positivista da época, a história era factual e pouco crítica. Em vez de se discutir a concentração de terras que excluía enormes setores da população do processo produtivo, mostravam-se heróis, governadores e presidentes responsáveis por tais e quais obras ou vitórias (NEMI e MARTINS, 1996: 16).

Durante o regime Vargas, especialmente durante a ditadura do Estado Novo, pouco se fez para melhoria do ensino de história, a qual foi utilizada para efetuar propaganda do Estado:

Nesse contexto de ditadura, o ensino de história voltou a ser mero instrumento de reprodução dos valores dominantes e de alienação. As aulas continuaram a se pautar pela sucessão de nomes e datas consideradas fundamentais pelos professores. Nas escolas técnicas nem sequer se ensinava história. (NEMI e MARTINS, 1996: 18).

No regime cívico-militar, depois do golpe de 1964, o ensino de história continuou sendo construído sobre heróis e em razão da censura, não apresentava nenhuma perspectiva crítica:

O ensino de história foi acoplado ao de geografia numa disciplina denominada estudos sociais. Perdendo a especificidade, tanto uma como outra tiveram reforçada sua característica original de reprodutoras de um saber construído pelas elite (NEMI e MARTINS, 1996: 20).

Nesta época, talvez em razão da censura, surgem historiadores, que apostavam numa visão mais crítica sobre a história, como Kenneth Maxwell, que exerceu forte influência nas pesquisas sobre o século XVIII luso-brasileiro. É também nesse período que os especialistas educacionais passaram a exigir mudanças nos currículos escolares. Todavia, no ensino básico, controlado pelo Estado, pouco se fez nessa direção. $\mathrm{O}$ recorte abaixo esclarece esse momento, pois foi

a partir dos anos 60 e 70, desenvolveu-se no Brasil o pensamento crítico, radical, de oposição e deslegitimação dos saberes históricos transmitidos na escola. Influenciado pelos teóricos da reprodução, o pensamento educacional critico passa a deslegitimar os currículos oficiais de história. A escola passa a ser encarada como aparelho de reprodução dos valores e idéias da classe dominante, e o ensino de historia, como mero veículo de reprodução de memória do vencedor (GUIMARÃES, 1998: 13).

Foi a partir dos anos 80, com a redemocratização política, que começou um redimensionamento do papel da instituição escolar e análise sobre os conteúdos dos livros de história. Porém, como apresentado nos exemplos acima, o processo é demorado e ainda neste princípio do século XXI há um desconhecimento, por parte dos alunos do ensino fundamental, de que a 
imagem de herói do Tiradentes, foi construída pelo poder republicano.

O livro didático atual busca enfatizar mais o caráter da Inconfidência Mineira do que o papel de Tiradentes como mártir. No recorte abaixo, de um livro publicado em 1999 já aparece o movimento descrito como uma revolta da elite e a foto caracterizando Tiradentes é a do quadro de José Wasth Rodrigues (Tiradentes como alferes), eliminando, assim, a imagem mais conhecida do herói como Cristo (de barba e cabelos compridos):

A Inconfidência Mineira não foi uma revolta de caráter popular. Visava apenas o fim da opressão portuguesa que prejudicava a elite mineira. Não tinha como finalidade acabar com a opressão social interna, que atingia a maioria da população. (COTRIM, 1999: 136).

Muito se engana quem pensa que a figura de Tiradentes esgotou seu manancial utilitário governamental. Através de textos com uma montagem de um perfil favorável de todos os inconfidentes, exceto pelos delatores, a figura de Tiradentes sobressai e acaba no discurso ou ato de qualquer político que deseja despertar interesse pela sua figura por parte do eleitorado ou governado:

\begin{abstract}
São as matrizes a partir das quais a história da Inconfidência Mineira tem sido predominantemente construída e difundida, especialmente pelos meios de comunicação e pela escola. Curioso é que, mesmo quando provenientes de posicionamentos políticos distintos e, as vezes, opostos, o pano de fundo elaborado nestas obras, com a preocupação de enaltecer o movimento e seu herói permanece inalterado (FONSECA, 2002: 12).
\end{abstract}

Vejamos, talvez, o caso mais interessante no passado recente de uso da imagem de Tiradentes.

A história sobre a morte de Tancredo Neves em 1985 é permeada por dúvidas e polêmicas. Porém, o que interessa aqui, é a data da morte do político mineiro que, coincidentemente, seria a mesma do enforcamento de Tiradentes. Especula-se que Tancredo havia morrido um dia antes, mas que desejavam que sua morte viesse a simbolizar o nascimento de um novo herói para a nação:

No caixão, ao contrário das tradicionais mãos postas do sepultamento cristão, o corpo foi colocado com os braços estendidos ao longo do corpo, para que os dedos arroxeados, que já apresentavam sinais de necrose, ficassem encobertos por flores.

Nessa história cercada por controvérsias e dissimulações, correu ainda a suspeita de que Tancredo Neves não teria morrido em 21 de abril, mas um dia antes, na noite de 20 de abril, quando seu cérebro deixara de funcionar. $\mathrm{O}$ anúncio da morte teria sido adiado para coincidir com a data simbólica, numa aproximação das figuras de Tancredo e Tiradentes, dois mártires que Minas deu à história nacional. Dois anos depois do ocorrido, tal versão seria sustentada em uma reportagem da Veja, amparada por uma declaração de um dos médicos que teria acompanhado o estado clinico de Tancredo até o fim (NETO, 2005: 53). 
Destarte, este fato já se tornou uma história que, por enquanto, ninguém pode confirmar. Tancredo, com certeza se tornou um mito, mas sua memória está muito ligada a quem presenciou aquele momento histórico. As novas gerações não guardam sua memória como a de Tiradentes.

\title{
A sobrevivência do mito
}

Nos dias atuais ainda se cultua a imagem de Tiradentes como comparada à imagem de Cristo. A historiografia contemporânea pode lutar para apagar esta visão de Tiradentes, mas isto dificilmente ocorrerá no correr de décadas. Este texto foi publicado no jornal Estado de Minas em abril de 2000:

\begin{abstract}
Hoje o coração do povo brasileiro vivencia a emoção de dupla cerimônia: uma religiosa e outra cívica, quando celebra-se a Sextafeira da Paixão e o Dia de Tiradentes, [...]. Coincidentemente, Cristo e Tiradentes morreram por causas nobres, visando o bem estar do homem. Cristo por pregar a verdade, o amor, a paz, a igualdade, na tentativa de libertar o homem do pecado. Tiradentes, por pregar e lutar pela tão sonhada liberdade do povo brasileiro, explorado e massacrado pela Coroa portuguesa, e por querer fazer deste País uma verdadeira nação. Um na cruz, outro na forca. Cristo após crucificado e sepultado, ressuscitou três dias depois, e hoje, em qualquer parte do planeta onde houver um cristão. O seu nome será aclamado e venerado. Tiradentes, depois de enforcado no Largo da Lampadosa, no ensolarado sábado de 21 de abril de 1792, teve seu corpo esquartejado e espalhado pelas estradas de Minas, para servir de exemplo. É intrigante. Uma pergunta cuja resposta nunca convence. Por que as pessoas de bem, honestas e dedicadas às causas alheias pagam tão alto por seus nobres gestos? (LIMA apud FONSECA, 2000: 453-454).
\end{abstract}

A estrutura deste texto é a mesma dos datados da segunda metade do século XIX, nos quais as analogias entre Tiradentes e Cristo, entre o mártir cristão e cívico, eram mais comuns. Ainda observamos um encerramento de fundo moral, com ênfase no sacrifício. São escritos como este, que circulam, através dos meios de comunicação, que têm contribuído eficazmente para a manutenção das representações de Tiradentes.

O professor Sérgio Vaz Alkmin, aponta como causas da perpetuação da figura de Tiradentes, além dos jogos políticos, o caráter cristão da sociedade brasileira:

\footnotetext{
A imitação de Cristo como modelo exemplar, a repetição de seus passos pela vida, a morte, a ressurreição, constituem a contemporaneidade do cristão. A imagem de Tiradentes, herói nacional, mito de origem moderno de nosso ideal de liberdade sobrevive no tempo. A historiografia da Inconfidência Mineira e o jogo de interesses políticos e ideológicos cumprem o papel de perpetuar o
} 
mito e alimentar ilusões no imaginário coletivo. O cenário é cristão (ALKMIN, 2006).

Outra justificativa para a permanência do mito em torno de Tiradentes seria a ignorância da maioria da "massa" a respeito das sentenças acadêmicas, como explícita, Paulo Miceli:

Tratar de Tiradentes, apesar das dificuldades e riscos, é sempre interessante. (...) nele, a história que as pessoas chamam real ou verdadeira confunde-se com a tradição que alimenta o imaginário popular. Confunde-se e vai confundir-se sempre, porque inscrita em um espaço impenetrável para a ciência, pois enquanto a universidade rejeita (para justificar sua própria existência) uma história que, à falta de evidencias, dá livre curso à imaginação e à fantasia, a "massa" (...) ignora soberba as opiniões e sentenças que a academia contínua emitindo (MICELI, 1994: 41).

Se a opinião da chamada "ciência" continua tendo dificuldade em chegar às mentes da chamada "massa", a transmissão oral, desta memória popular, perpetuará a imagem cristalizada em torno de Tiradentes como herói sacrificado e divinizado. Mesmo que a escola ou o livro didático não coloque o herói em voga, todo dia vinte e um de abril, alguma criança perguntará aos seus pais, quem foi Tiradentes, e histórias sobre um grande herói surgirão.

Uma imagem que até os historiadores mais críticos não ousam macular:

Não pretendo diminuir ou menosprezar Tiradentes. Ele foi, sem dúvida, o catalisador da Revolução na conturbada Minas de 1788. Um decidido propagandista de uma Minas Gerais independente, republicana e auto-suficiente, ele pretendia desencadear a revolta. Se as circunstâncias não o tivessem impedido, não há dúvida de que, ao contrário de alguns companheiros de conspiração, teria partido para a ação a que se propusera (MICELI, 1994: 41).

Assim, sobrevive o mito do mártir, do sacrificado. Tiradentes acaba por se tornar um herói republicano, por desejar a liberdade e representar o alto grau do civismo. Sua personalidade transforma-se quase em divina, como diria Mircea Eliade: “(...) as personagens do mito não são seres humanos: são deuses ou heróis civilizadores” (ELIADE, 2001: 84).

\section{Considerações Finais}

Quando esta pesquisa teve início, continha o caráter de encontrar alguma "verdade" sobre Tiradentes. Com a finalização dos trabalhos, acabou-se deparando com várias "verdades", que foram produzidas por ideologias e em momentos diferentes. Encontramos discursos e contra-discursos, memórias que se chocam com outras memórias e imagens que rebatem outras imagens. 
Para o historiador todas as imagens, discursos e memórias devem se tornar documentos válidos. Estes materiais demonstram o contexto de uma época, o pensamento de um grupo que seguia tal ideologia ou uma realidade que certo povo ou comunidade, não conseguiam enxergar, naquele determinado período.

Existe uma citação na referida obra Como se escreve a História?, de Paul Veyne, na qual, o autor compara a história a um palácio, do qual, não descobrimos ainda toda a extensão, sendo para nós um complexo parecido com um labirinto, no qual, a ciência pode nos auxiliar a encontrar algumas saídas, mas que nunca seria capaz de nos entregar a planta do prédio (VEYNE, 1998: 133).

Nesta citação, Veyne comenta sobre as várias possibilidades de se fazer história, pois é uma matéria que está em andamento, sempre a ser reconstruída.

Dentro deste espírito de pensamento, poderia ser acrescentado, que este palácio possui um sótão, no qual, são depositadas as histórias esquecidas, as versões dos perdedores e as versões que estão fora de uso. Possui, ainda, salas secretas, nas quais, fatos históricos podem ser observados sobre um novo ângulo e que depende da astúcia do historiador, para poder adentrá-las.

Nesta pesquisa, concluímos que não importa descobrir se Tiradentes foi um herói ou um "bode expiatório" que levou a culpa, para livrar seus companheiros da forca. O que interessa é o por que de sua memória continuar tão viva, mais de duzentos anos depois de sua morte.

Uma memória que foi implementada pelo "poder dominante" e que, nesta operação, utilizou-se da história e dos meios de comunicação para alcançar seu objetivo, que é a implantação de uma ideologia.

Tiradentes pode ser como Cristo para os religiosos, como o republicano cívico para o cidadão, a figura exemplar para o político se comparar, uma boa história para o historiador ou romancista, e, o mais importante, um brasileiro que morreu por seu ideal.

A História Nacional ainda está sendo escrita e como comenta José Carlos Reis, é muito complicado para o povo que está vivendo sua própria realidade, observar profundamente o que se passa no interior dos acontecimentos. (REIS, 1999: 07)

O historiador, também, corre o risco de estar auxiliando ou transmitindo 
uma ideologia imposta. É necessário ao profissional de história, seja ele um pesquisador ou professor, observar a máquina dominante e a própria história vivida, para não cair nesta armadilha.

\section{Bibliografia}

ALKMIM, Sérgio Vaz. A origem do mito e o mito de origem. Disponível em: $<$ http://gold.br.inter.net/luisinfo/cidadania/tiradentes.htm >.

AZEVEDO, Silvia Maria. Patrimônio e memória. São Paulo: UNESP-PCLASCEDAP, 2005, v. 1, $\mathrm{n}^{\mathrm{O}} .1$.

BAZCO, Bronislaw. Imaginação social. IN: Memória-História. Trad. Bernardo Leitão et all. Portugal [Porto]: Imprensa Nacional:Casa da Moeda, 1984, p. 298332 (Enciclopédia Einaudi, v. 1.).

BLOCH, Marc. Apologia da História: ou o ofício do historiador. Trad. André Telles. Rio de Janeiro: Zahar, 2001.

BENJAMIN, Walter. Obras escolhidas. Trad. Sérgio Paulo Rouanet. São Paulo. Brasiliense, 1987.

CARDOSO, Ciro Flamarion e VAINFAS, Ronaldo. Domínios da História. Rio de Janeiro: Campus, 1997.

CARVALHO, José Murilo de. A formação das almas: o imaginário da República no Brasil. São Paulo: Companhia das Letras,1990.

CARMO, Sonia Irene do e COUTO, Eliane. História Passado Presente: Brasil Colônia. Campinas / SP: Atual, 1998.

CHAUÍ, Marilena. O Discurso competente. São Paulo: Moderna. 1982

CHIAVENATO, Julio José. As várias faces da Inconfidência Mineira. São Paulo: Contexto, 1994.

COGGIOLA, Osvaldo. Org. A revolução Francesa e seu impacto na América Latina. São Paulo: Nova Stella; Editora da Universidade de São Paulo, 1990.

CODECEIRA, José Domingues. A idéia republicana no Brasil. 2. ed. Recife (Pe): Massangana, 1990.

COSTA, Emília Viotti da. Da Monarquia à República: momentos decisivos. 7 . ed. São Paulo: Fundação Editora da UNESP, 1999.

COTRIM, Gilberto. História e consciência do Brasil. São Paulo: Saraiva, 1999.

ELIADE, Mircea. O sagrado e o profano: a essência das religiões. 3. ed. Trad. Rogério Fernandes. São Paulo: Martins Fontes, 2001.

FALCON, Francisco J.C. A identidade do historiador. Anais do XVIII Simpósio Nacional da ANPUH. Recife (Pe), julho de 1995, pp.

FERREIRA, Marieta de Moraes. Entrevista com Jacques Revel. Paris. Fev. 1997. Disponível em:<http://www.cpdoc.fgv.br/revista/arq/214.pdf>

FERRO, Marc. A história vigiada. Trad. Maria Ângela Villela. São Paulo: Martins Fontes, 1989.

FONSECA, Thais N. de Lima e. A inconfidência Mineira e Tiradentes vistos pela 
Imprensa: a vitalização dos mitos. Revista Brasileira de História. São Paulo: ANPUH:Marco Zero, vol. 22, $n^{\circ}$. 44, pp. 439-62.

FOUCAULT. Microfísica do Poder. Trad. Roberto Machado. São Paulo: Graal, 1982.

FURTADO, Júnia Ferreira. Homens de negócio: a interiorização da metrópole e o comércio nas minas setecentistas. São Paulo: HUCITEC, 1999.

GIRARDET, Raoul. Mitos e mitologias políticas. Trad. Maria Lucia Machado. São Paulo: Companhia das Letras, 1987.

GUIMARÃES, Selma. Didática e prática de ensino de história. Belo Horizonte (MG): Papirus, 1998.

HONORATO, César Teixeira. Inconfidentes Mineiros: versos ternos. Palavras duras. IN: COGGIOLA, Osvaldo (org.). A revolução Francesa e seu impacto na América Latina. São Paulo: Nova Stella: Ed. da Universidade de São Paulo, 1990.

JARDIM, Silva. Tiradentes. Discurso no Club Tiradentes. Rio de Janeiro: Typographia. G. Leuzinger \& Filhos, 1890.

JENKINS, Keith. A história repensada. Trad. Marco Aurélio Werle. São Paulo: Contexto, 2001.

LE GOFF, Jacques (org.). A nova história. Trad. Eduardo Leitão. Rio de Janeiro: Francisco Alves, 1978.

LE GOFF, Jacques. Memória. IN: Memória-História. Trad. Bernardo Leitão e outros. Portugal: [Porto]: Imprensa Nacional: Casa da Moeda, 1984 (Enciclopédia Einaudi, v. 1).

LETTIÉRE, Roberto. A inconfidência Mineira e a Maçonaria Brasileira. Londrina (Pr.): Boa Vista, 2001.

MARTINS, Ana Luzia. República: um outro olhar. São Paulo: Contexto. 1996.

MATTOS, Hebe Maria. A escravidão moderna nos quadros do Império português. IN: FRAGOSO, João et all. O Antigo Regime nos trópicos: a dinâmica imperial portuguesa (séculos XVI e XVIII). Rio de Janeiro: Civilização Brasileira, 2000.

MAXWELL, Keneth R. A devassa da devassa. Trad. João Maia. 2. ed. Rio de Janeiro: Paz e Terra,1978.

MICELI, Paulo. Mitos, heróis e outros bichos. Seminário 500 anos de História do Brasil. Campinas: UNICAMP, 2000, p. 2.

MICELI, Paulo. O mito do herói nacional. São Paulo: Contexto, 1994.

MOTA, Carlos Guilherme. A idéia de revolução no Brasil (1789-1801). Petrópolis: Vozes, 1979.

MURY, Lydia. Tiradentes. São Paulo: Editora Três. 1973.

NEMI, Ana Lúcia Lana e MARTINS, João Carlos. Didática e História: o tempo vivido. São Paulo: FTD, 1996.

NETO, Lira. Tancredo: martírio e morte. Revista Aventuras na História. São Paulo: Abril Cultural, abr. 2005, no. 20, p. 53. 
NORA, Pierre e BLOCH, Marc (orgs.). Como se escreve a história. Trad. André Telles. Rio de Janeiro: Francisco Alves, 1976.

OILIAN, José. Tiradentes. Belo Horizonte: Imprensa Oficial, 1974.

PILETTI, Nelson e PILETTI, Claudino. História e vida: vol. 1. São Paulo: Moderna, 1989.

PINCA, Laura. Tiradentes, o bode expiatório. Montfort Associação Cultural. Disponível em $<$ http://www.montfort.org.br/index.php?secao=veritas\&subsecao=historia\&art igo=tiradentes\&lang=braOnline $>$

REIS, José Carlos. A História entre a Filosofia e a Ciência. São Paulo: Ática, 1996.

2000.

. As identidades do Brasil: de Varnhagen a FHC. Rio de Janeiro: FGV,

RODRIGUES, Tereza. História Brasil Colonial. São Paulo: IBEP, 1994.

SCHAFF, Adam. História e verdade. Trad. Maria Paula Duarte. São Paulo: Martins Fontes, 1978.

SENA, Carlos Zacarias F. A dialética em questão: considerações históricometodológicas sobre a historiografia contemporânea. Revista Brasileira de História. São Paulo: v. 24, no 48, 2004.

SILVA, Maria Beatriz Nizza. Teoria da História. São Paulo: Arte X, 1986.

SOUTHEY, Robert. História do Brasil. Trad. Luiz Joaquim de Oliveira e Castro. 3.ed. São Paulo: Obelisco, 1965.

SOUZA, Laura de Melo. Os desclassificados do ouro: a pobreza mineira no século XVIII. Rio de Janeiro: Graal, 1982.

VARNHAGEN, Francisco Adolfo. História Geral do Brasil. Belo Horizonte: Lemi, 1980.

VEYNE, Paul. Como se escreve a História e Foucault revoluciona a história. Trad. Alda Balttar e Maria Auxiliadora Kneipp. Brasília: UNB, 1998.

WEHLING, Arno. Estado, História, Memória: Varnhagen e a construção da Identidade Nacional. Rio de Janeiro: Nova Fronteira, 1999.

Colaboração recebida em 30/03/2009 e aprovada em 26/06/2009. 